\title{
Interaction of Fish Muscle Glycolytic Enzymes with F-Actin and Actomyosin
}

\author{
Takayuki Nakagawa* and Fumio Nagayama* \\ (Received August 31, 1988)
}

\begin{abstract}
The binding of fish muscle glycolytic enzymes with F-actin and actomyosin was studied in vitro under various conditions. The binding of glucosephosphate isomerase, phosphoglycerate kinase and enolase with the myofibrillar proteins was weak, while that of aldolase and glyceraldehyde-3-phosphate dehydrogenase was strong. The latter enzymes showed the ratio of the unbound to total enzyme ranging from $9-50 \%$, when mixed with $F$-actin or actomyosin. The recovery of bound enzyme ranged from 61 to $86 \%$ for aldolase and from 60 to $92 \%$ for glyceraldehyde3-phosphate dehydrogenase.

The enzyme-myofibrillar protein binding was depressed by the increase in reaction $\mathrm{pH}, \mathrm{KCl}$ or $\mathrm{Ca}^{2+}$ concentration. In the presence of $150 \mathrm{~mm} \mathrm{KCl}$ or $50 \mathrm{mM} \mathrm{Ca}^{2+}$, the binding was inhibited almost completely. Glycolytic metabolites also influenced the binding. Fructose-1,6-bisphosphate and 2,3-bisphosphoglycerate caused a marked adsorption-hindrance for aldolase at a concentration of $1 \mathrm{~mm}$. The results obtained could account for the enzyme-specific extractability from fish muscle.
\end{abstract}

Several glycolytic enzymes such as aldolase and glyceraldehyde-3-phosphate dehydrogenase from mammalian muscle have been shown to bind reversibly to the structural muscle proteins, especially to F-actin. ${ }^{1-4)}$ This binding was confirmed by histochemical observations of rabbit muscle, which revealed the binding site of glycolytic enzymes to be the I band. ${ }^{5)}$ The binding of aldolase and glyceraldehyde-3-phosphate dehydrogenase to Factin is influenced not only by $\mathrm{pH}$ and ionic strength but also by the specific action of certain metabolites and metal ions. ${ }^{2-4)}$

The extractability of sarcoplasmic proteins from fish muscle at low-ionic strengths was species-specific, ${ }^{6)}$ with a low extractability in marine pelagic (red-fleshed) fish probably due to the interaction of sarcoplasmic proteins with myofibrils. ${ }^{7)}$ In a previous paper, ${ }^{8)}$ we examined extractability of several glycolytic enzymes from the ordinary muscle of red sea bream, Pacific mackerel and carp and found the dependency on $\mathrm{KCl}$ concentration of the extractability of aldolase, glyceraldehyde-3-phosphate dehydrogenase and glucosephosphate isomerase, suggesting an interaction between glycolytic enzymes and myofibrillar proteins at low-ionic strengths.

To characterize further the interaction between glycolytic enzymes and myofibrillar proteins, we carried out this time a model experiment in which some glycolytic enzymes and F-actin (or acto- myosin) were reacted under various conditions.

\section{Materials and Methods}

\section{Fishes}

The ordinary muscle form frozen specimens of red sea bream Pagrus major, Pacific mackerel Scomber japonicus and carp Cyprinus carpio was used as the material.

\section{Protein Preparations}

Sarcoplasmic proteins containing glycolytic enzymes were prepared by the method of Clarke and Masters ${ }^{9)}$ with slight modifications as follows. The ordinary muscle of each species was minced and stirred vigorously with 3 volumes of $0.1 \mathrm{M}$ phosphate buffer $(\mathrm{pH} 7.5)$ containing $2 \mathrm{~mm}$ dithiothreitol (DTT) and centrifuged at $15,000 \times$ for $20 \mathrm{~min}$. The supernatant was subjected to ammonium sulfate fractionation between $35 \%$ and $90 \%$ saturations. The resulting precipitate was collected and dissolved in $0.05 \mathrm{M}$ Tris- $\mathrm{HCl}$ buffer ( $\mathrm{pH} 7.5$ ) containing $5 \mathrm{~mm}$ EDTA and $2 \mathrm{~mm}$ DTT. The sarcoplasmic proteins thus obtained was suspended in a saturated ammonium sulfate solution, and kept at $4^{\circ} \mathrm{C}$ until use.

$\mathrm{F}$-actin and actomyosin were prepared from rabbit fast muscle by the method of Spudich and Watt $^{10)}$ and Ebashi, ${ }^{11)}$ respectively.

Sodium dedecylsulfate (SDS)-gel electrophore-

* Tokyo University of Fisheries, Konan, Minato, Tokyo 108, Japan (中川孝之, 氷山文男：東京水産大学). 
sis was carried out using $10 \%$ polyacrylamide gels containing $0.1 \%$ SDS. ${ }^{12)}$

\section{Binding Studies}

Binding studies were performed according to the method of Clarke and Masters ${ }^{4)}$ with some modifications as follows. The stock sarcoplasmic protein suspension was exhaustively dialyzed against $5 \mathrm{~mm}$ imidazole- $\mathrm{HCl}$ buffer ( $\mathrm{pH}$ 6.8) containing $1 \mathrm{mM} \mathrm{MgCl}_{2}$ and $2 \mathrm{~mm}$ DTT, and centrifuged at $10,000 \times \mathrm{g}$ for $20 \mathrm{~min}$ to remove insoluble substances. The supernatant was diluted with the same buffer so that the sarcoplasmic protein concentration was $0.5 \mathrm{mg} / \mathrm{m} /$. In a centrifugal tube, F-actin or actomyosin pellet (containing 5$10 \mathrm{mg}$ protein) obtained by the dilution-precipitation procedure ${ }^{11)}$ was prepared, and to it was added $2 \mathrm{~m} /$ of the above sarcoplasmic protein solution. The mixture thus provided was incubated at $25^{\circ} \mathrm{C}$. After $20 \mathrm{~min}, 0.2 \mathrm{~m} l$ of the mixture was taken out and immediately cooled in ice for determination of the total enzymatic activity (A) by the method described below. The remainder was centrifuged at $156,000 \times \mathrm{g}$ for $60 \mathrm{~min}$ at $4^{\circ} \mathrm{C}$, and the supernatant was similarly assayed for enzymatic activity (B).

The bound enzyme $(\%)$ was defined as the ratio of $(\mathrm{A}-\mathrm{B}) / \mathrm{A}$.

The precipitate obtained by the above centrifugation was suspended in $2 \mathrm{~m} l$ of $0.1 \mathrm{M}$ phosphate buffer ( $\mathrm{pH}$ 7.6) containing $0.15 \mathrm{M} \mathrm{KCl}$, and centrifuged in the same manner. The activity in the supernatant obtained was measured.

The same procedure in the absence of F-actin or actomyosin was also performed to estimate the activity decreased by precipitation of sarcoplasmic proteins.

\section{Assays}

Activities of glucosephosphate isomerase (GPI; EC 5.3.1.9), aldolase (ALD; EC 4.1.2.13), glyceraldehyde-3-phosphate dehydrogenase (GAPDH; EC 1.2.1.12), phosphoglycerate kinase (PGK; EC 2.7.2.3) and enolase (ENO; EC 4.2.1.11) and protein concentration were measured by the same methods as described in the previous paper. ${ }^{8)}$

\section{Results and Disccusion}

The electrophoretic patterns of sarcoplasmic proteins from the ordinary muscle of red sea bream, Pacific mackerel and carp were speciesspecific as reported previously ${ }^{13)}$ (Fig. 1). The composition in sarcoplasmic proteins was, however, not taken into consideration in the following experiments. The F-actin preparation from rabbit fast muscle showed a single band in SDS-gel electrophoresis, and the actomyosin preparation was almost free from glycolytic enzymes such as ALD and GAPDH.

The binding of several glycolytic enzymes to these myofibrillar proteins was measured at dif-

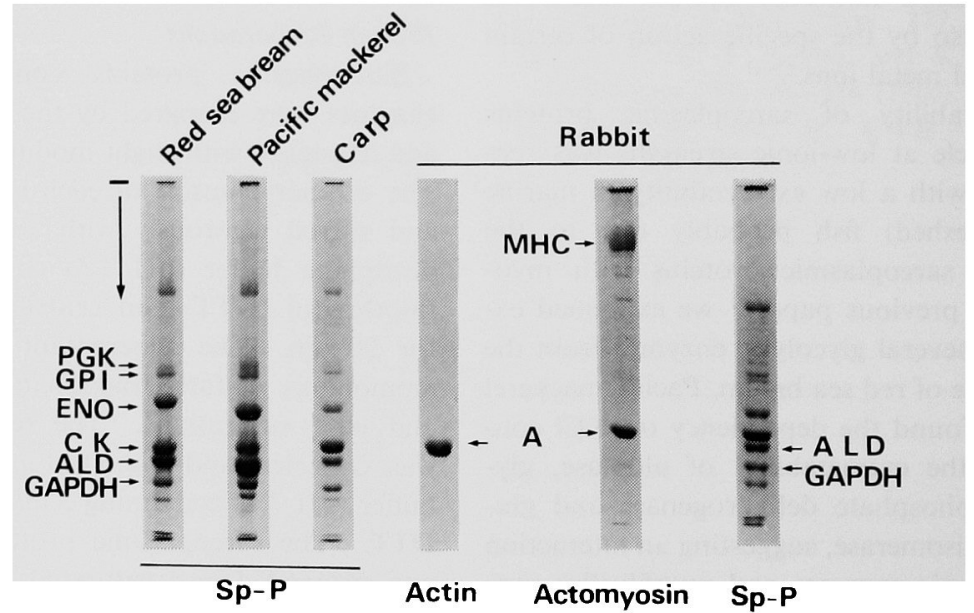

Fig. 1. SDS-gel electrophoretic patterns of sarcoplasmic proteins from the ordinary muscle of three fish species, and of actin, actomyosin and sarcoplasmic proteins from rabbit fast muscle. Sarcoplasmic proteins from rabbit were extracted with 5 volumes of $50 \mathrm{~mm}$ phosphate buffer (pH 7.5).

Abbreviations used: $\mathrm{MHC}$, myosin heavy chain; A, actin; Sp-P, sarcoplasmic proteins; ALD, aldolase; GAPDH, glyceraldehyde-3-phosphate dehydrogenase; PGK, phosphoglycerate kinase; GPI, glucosephosphate isomerase; ENO, enolase; and CK, creatine kinase. 


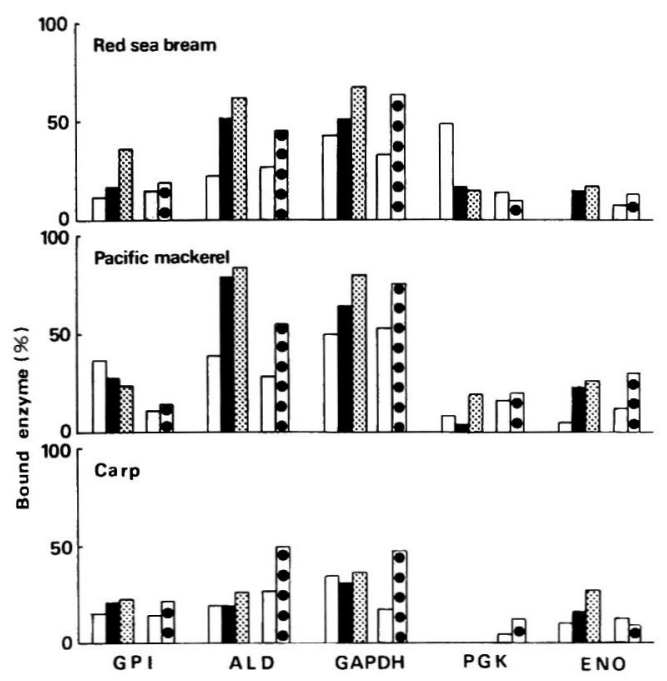

Fig. 2. Effect on the binding of fish glycolytic enzymes to F-actin (or actomyosin) of their relative proportions. In a final volume of $2 \mathrm{ml}$ of $5 \mathrm{~mm}$ imidazole- $\mathrm{HCl}$ buffer ( $\mathrm{pH}$ 6.8) containing $1 \mathrm{~mm}$ $\mathrm{MgCl}_{2}$ and 2 mM DTT.

$\square, 5 \mathrm{mg}$ F-actin and $2 \mathrm{mg}$ sarcoplasmic proteins; $5 \mathrm{mg}$ F-actin and $1 \mathrm{mg}$ sarcoplasmic proteins; $\because \because \because, 10 \mathrm{mg}$ F-actin and $1 \mathrm{mg}$ sarcoplasmic proteins; $5 \mathrm{mg}$ actomyosin and $1 \mathrm{mg}$ sarcoplasmic proteins; $\underline{\underline{\mathbf{0}}}, 10 \mathrm{mg}$ actomyosin and $1 \mathrm{mg}$ sarcoplasmic proteins.

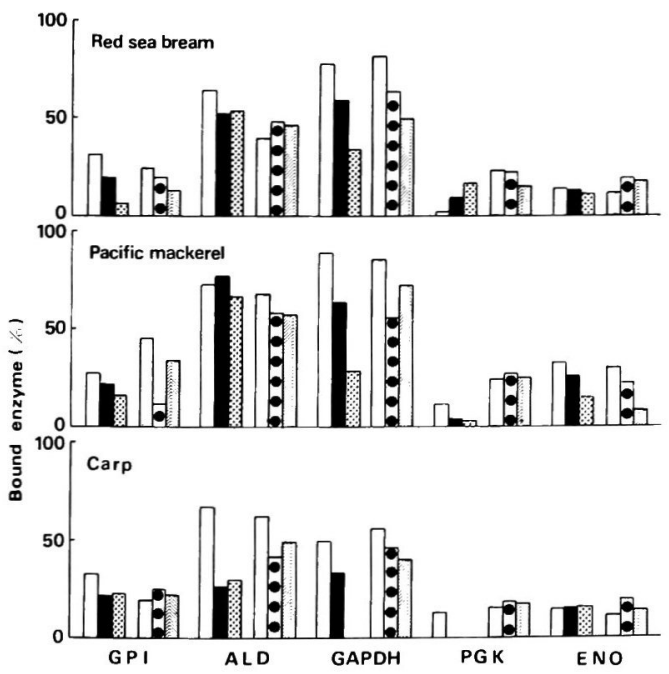

Fig. 3. Effect of $\mathrm{pH}$ on the binding of fish glycolytic enzymes to F-actin or actomyosin. Five $\mathrm{mg}$ of $\mathrm{F}$-actin and $1 \mathrm{mg}$ of sarcoplasmic proteins were reacted in $5 \mathrm{~mm}$ imidazole- $\mathrm{HCl}$ buffer containing $1 \mathrm{~mm} \mathrm{MgCl}_{2}$ and $2 \mathrm{~mm}$ DTT at pH 6.0 ( $\square$ ), $\mathrm{pH} 6.8$ ( $)$ and $\mathrm{pH} 7.4(\because \because)$. Ten $\mathrm{mg}$ of actomyosin and $1 \mathrm{mg}$ of sarcoplasmic proteins were reacted in $5 \mathrm{~mm}$ imidazole- $\mathrm{HCl}$ buffer containing $1 \mathrm{mM} \mathrm{MgCl}_{2}$ and $2 \mathrm{mM}$ DTT at $\mathrm{pH} 6.0$

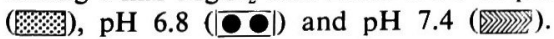

ferent protein concentrations, and the results obtained are shown in Fig. 2. Within the range of protein concentrations examined, there was no binding of carp PGK to F-actin, whereas other enzymes were more or less bound to F-actin or actomyosin under the same conditions. During the binding experiments, the activity decreased by precipitation of sarcoplasmic proteins in the absence of F-actin or actomyosin was around $2 \%$ of the original activity. The bound enzyme (\%) generally increased by the decrease of the weight ratio of sarcoplasmic proteins to F-actin or actomyosin. ALD and GAPDH of the three species, especially of Pacific mackerel, showed a high bound ratio to F-actin or actomyosin, while GPI, PGK and ENO showed low ratios.

The influence of $\mathrm{pH}$ on the binding of fish enzymes to F-actin or actomyosin is shown in Fig. 3.

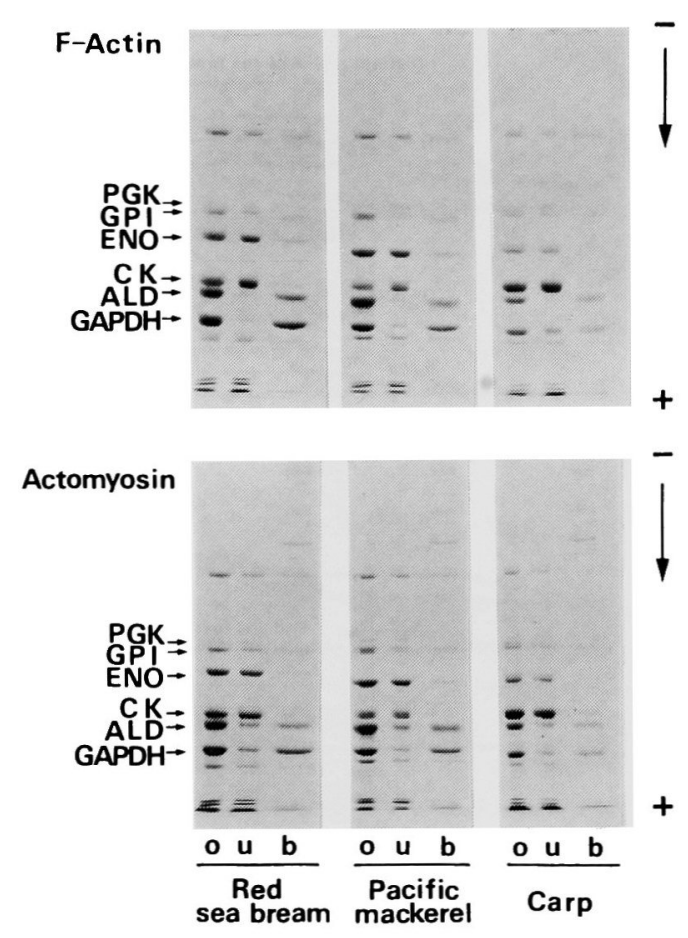

Fig. 4. SDS-gel electrophoretic patterns of F-actin (or actomyosin)-bound and unbound fractions. In binding experiments, $5 \mathrm{mg}$ of $\mathrm{F}$-actin (or $10 \mathrm{mg}$ of actomyosin) and $1 \mathrm{mg}$ of sarcoplasmic proteins were reacted at $\mathrm{pH}$ 6.8. After binding, bound enzymes were extracted from the complex formed with $0.1 \mathrm{M}$ phosphate buffer ( $\mathrm{pH}$ 7.6) containing $0.15 \mathrm{M} \mathrm{KCl}$, and subjected to electrophoresis as "bound fraction".

$o$, original sarcoplasmic proteins; $u$, unbound fraction; and $b$, bound fraction. 
In a $\mathrm{pH}$ range between 6.0 and 7.4 , the amount of bound enzyme decreased by the increase of $\mathrm{pH}$, especially in the case of GAPDH. On the other hand, the binding of those enzymes to actomyosin was not so much influenced by $\mathrm{pH}$. The binding of Pacific mackerel ALD to myofibrillar proteins was not so markedly affected by $\mathrm{pH}$. Arnold et $a$ l. $^{3)}$ reported that rabbit muscle ALD was mostly bound to F-actin in a $\mathrm{pH}$ range from 6.5 to 7.5 .

As reported previously, ${ }^{, 2}$ ALD and GAPDH from Pacific mackerel were extracted more easily with $0.3 \% \mathrm{NaHCO}_{3}$ containing $0.15 \% \mathrm{NaCl}(\mathrm{pH}$ $8,6)$ than with water. As is widely accepted, the muslce of red-fleshed fish such as mackerel shows a good gel-forming ability when washed with the above solution to remove sarcoplasmic proteins which inhibit gel formation. ${ }^{14}$ ) The present results demonstrated that the interaction of glycolytic enzymes with myofibrillar proteins containing $\mathrm{F}$ actin was weakened under the mild alkaline conditions. Some part of Pacific mackerel ALD was, however, still retained in the muscle fibers.

SDS-gel electrophoretic patterns of the unbound and bound fractions of sarcoplasmic proteins to F-actin or actomyosin are shown in Fig. 4. ALD and GAPDH bands detected in the bound fraction from the three fish species were dense, while the other components of sarcoplasmic proteins were mainly detected in the unbound fraction, showing their little interaction with $\mathrm{F}$-actin or actomyosin under the conditions applied.

The distribution of enzymes between the unbound and bound fractions is shown in Fig. 5, together with the total recovery of their activities. The total activities of GPI, PGK and ENO recovered were $99.6-118.5 \%$ for F-actin and 92.4 $109.1 \%$ for actomyosin, whereas those of ALD
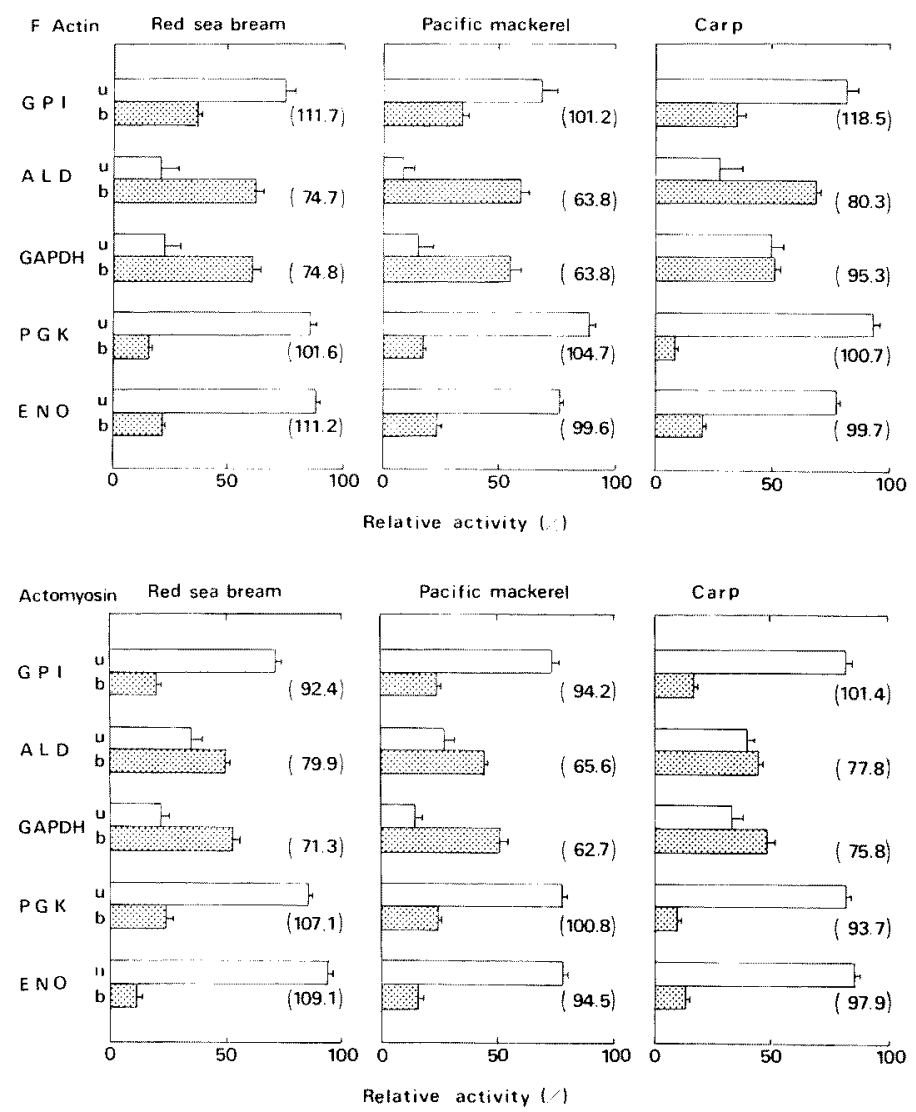

Fig. 5. Activity distribution of glycolytic enzymes between unbound ( $u, \square$ ) and bound (b, $\therefore \because$ ) fractions to $F$-actin or actomyosin. In binding experiments, $5 \mathrm{mg}$ of $\mathrm{F}$-actin (or $10 \mathrm{mg}$ of actomyosin) and $1 \mathrm{mg}$ of sarcoplasmic proteins were reacted at $\mathrm{pH} 6.8$. Numbers in parenthesis represent the total recovery of enzymatic activity. Bars represent the standard deviations. Refer to the legend in Fig. 4 for the determination of "bound fraction." 
Table 1. Effect of metabolites on the binding of Pacific mackerel aldolase (ALD) and glyceraldehyde-3-phosphate dehydrogenase (GAPDH) to F-actin.

The binding experiments were performed in a final volume of $2 \mathrm{ml}$ of $5 \mathrm{~mm}$ imidazole$\mathrm{HCl}$ buffer (pH 6.8) containing $1 \mathrm{mM} \mathrm{MgCl}_{\mathrm{\Omega}}$ and $2 \mathrm{mM}$ DTT, $5 \mathrm{mg}$ F-actin, $1 \mathrm{mg}$ sarcoplasmic proteins, and each metabolite at 0.1 and $1.0 \mathrm{~mm}$

\begin{tabular}{lcccc}
\hline \multicolumn{1}{c}{ Metabolite } & \multicolumn{5}{c}{ Binding to F-actin $(\%)^{*}$} \\
\cline { 2 - 5 } & \multicolumn{2}{c}{ ALD } & \multicolumn{1}{c}{ GAPDH } \\
\hline Fructose-1,6-bisphosphate & $(0.1 \mathrm{mM})$ & $(1.0 \mathrm{mM})$ & $(0.1 \mathrm{mM})$ & $(1.0 \mathrm{mM})$ \\
Glucose-1-phosphate & 45 & 34 & 100 & 86 \\
Glucose-6-phosphate & 89 & 94 & 100 & 100 \\
Fructose-6-phosphate & 89 & 84 & 94 & 100 \\
3-Phosphoglycerate & 96 & 97 & 100 & 78 \\
2,3-Bisphosphoglycerate & 91 & 35 & 60 & 45 \\
2-Phosphoglycerate & 33 & 30 & 96 & 74 \\
Phosphoenolpyruvate & 74 & 23 & 100 & 100 \\
Adenosine-5'-triphosphate & 88 & 62 & 100 & 95 \\
Adenosine-5'-diphosphate & 85 & 72 & 100 & 94 \\
Adenosine-5'-monophosphate & 81 & 75 & 72 & 95 \\
\hline
\end{tabular}

* The activity value obtained without any of these metabolites was taken as $100 \%$. Refer to the text for further details.

and GAPDH, $63.8-95.3 \%$ for F-actin and 62.7$79.9 \%$ for actomyosin. Judging from SDS-gel electrophoretic patterns (Fig. 4), the low recovery of ALD and GAPDH may be due to the insufficient solubilization of enzyme with $0.1 \mathrm{M}$ phosphate buffer ( $\mathrm{pH} \mathrm{7.6)} \mathrm{containing} 0.15 \mathrm{M} \mathrm{KCl}$. It has been reported that ALD and GAPDH were directly bound to the filaments, while other enzymes were bound over the above enzymes. ${ }^{15}$ )

As shown in Table 1, the binding of ALD and GAPDH to F-actin was also influenced by several metabolites. Fructose-1,6-bisphosphate (FBP) and 2,3-bisphosphoglycerate (2,3-BPG) had a significant effect on the binding of ALD at a concentration of $0.1 \mathrm{~mm}$. Moreover, 3-phosphoglycerate and 2-phosphoglycerate caused a marked effect on binding at a concentration of $1 \mathrm{~mm}$ as did FBP and 2,3-BPG. Hexosemonophosphates such as glucose-1-phosphate, glucose-6-phosphate and fructose-6-phosphate had little effect on the enzyme binding. Only 2,3-BPG depressed the binding of GAPDH at both concentrations. Inhibitory effect of FBP on ALD binding occurred at physiological FBP levels. ${ }^{18-19}$ ) It is, however, not clear whether this effect resulted from its specificity as the substrate for ALD or only from FBP concentration.

The ionic strength is one of the most important factors in the interaction between sarcoplasmic and myofibrillar proteins. ${ }^{2-4)}$ The enzyme binding to actomyosin was examined in various $\mathrm{KCl}$ concentrations covering a range from 0 to $150 \mathrm{~mm}$. As $\mathrm{KCl}$ concentration was increased, the binding

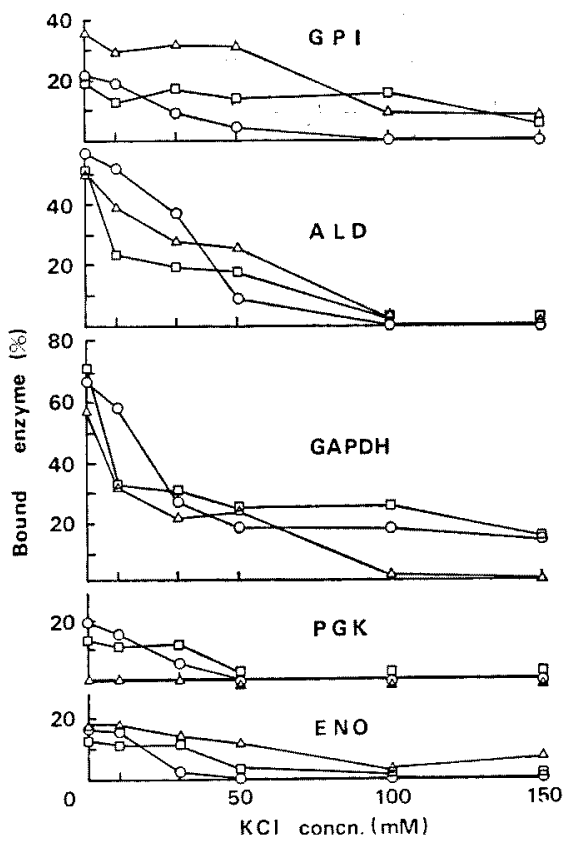

Fig. 6. Effect of $\mathrm{KCl}$ concentration on the binding to actomyosin of muscle glycolytic enzymes from red sea bream ( $\square$ ), Pacific mackerel $(O)$ and carp $(\triangle)$. Ten $\mathrm{mg}$ of actomyosin and $1 \mathrm{mg}$ of sarcoplasmic proteins were reacted at $\mathrm{pH} 6.8$. Refer to the legend in Fig. 4 for the determination of "bound fraction".

amount of ALD, GAPDH and GPI was decreased (Fig. 6). In the presence of $150 \mathrm{~mm} \mathrm{KCl}, 80$ $100 \%$ of enzyme was not bound to actomyosin. 


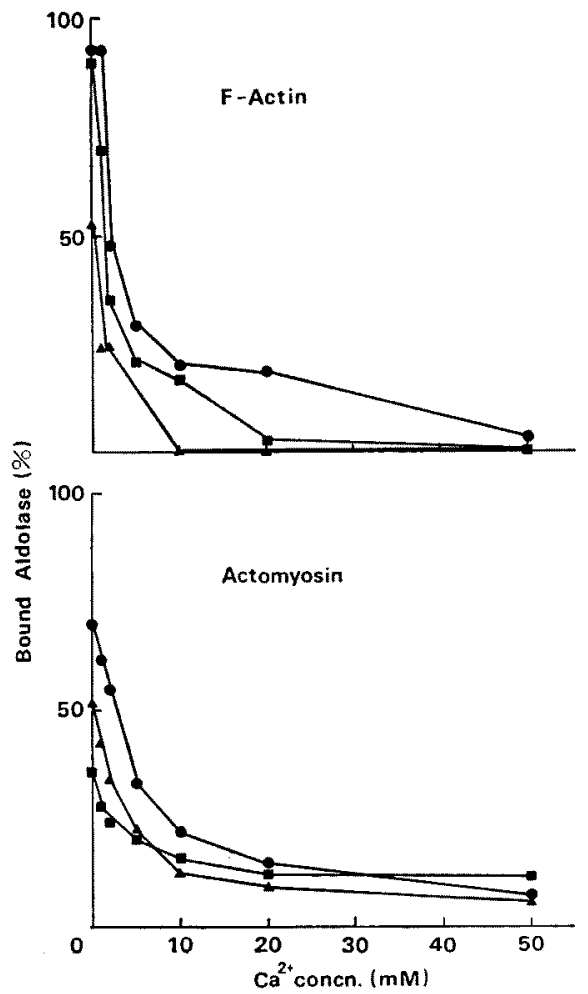

Fig. 7. Effect of $\mathrm{Ca}^{2+}$ concentration on the binding to F-actin or actomyosin of aldolase from the ordinary muscle of red sea bream (a), Pacific mackerel (O) and carp (A).

Five $\mathrm{mg}$ of F-actin (or $10 \mathrm{mg}$ of actomyosin) and $1 \mathrm{mg}$ of sarcoplasmic proteins were reacted at pH 6.8. Refer to the legend in Fig. 4 for the determination of "bound aldolase".

SDS-gel electrophoretic patterns also revealed that these enzymes tended not to bind with myofibrillar proteins as $\mathrm{KCl}$ concentration was increased (data not shown). On the other hand, the intensities of PGK and ENO bands were almost the same, irrespective of $\mathrm{KCl}$ concentration. Arnold and Pette ${ }^{2)}$ reported that the $\mathrm{KCl}$ concentration required for desorption of enzyme was higher than that for the adsorption-hindrance of enzyme. In the present study, similar results were obtained for ALD and GAPDH; that is, the binding of these enzymes almost completely depressed in the presence of $150 \mathrm{mM} \mathrm{KCl}$, while the release of the bound enzyme at the same $\mathrm{KCl}$ concentration was $61-78 \%$ for ALD and $60-73 \%$ for GAPDH. It is therefore recommended that during "kamaboko" processing, minced fish meat must be washed as soon as possible, because otherwise interactions between these glycolytic enzymes and myofibrillar proteins may proceed further.

The effect of $\mathrm{Ca}^{2+}$ concentration on the binding of fish muscle ALD to F-actin and actomyosin was examined (Fig. 7). The amount of bound ALD, irrespective of fish species, decreased with the increase of $\mathrm{Ca}^{2+}$ concentration. In the presence of $10 \mathrm{mM} \mathrm{Ca}^{2+}$, the amount of bound ALD of Pacific mackerel to actomyosin decreased to onethird of that in the absence of $\mathrm{Ca}^{2+}$.

The major glycolytic enzymes are located at the I-band of muscle fiber, and in vitro binding studies using fish sarcoplasmic proteins have confirmed this. ${ }^{5)}$ Moreover, the results of the present binding study correlated well with the extractability of glycolytic enzymes from the fish muscles. ${ }^{8)}$ Further experiments are necessary to examine the binding of glycolytic enzymes to F-actin or actomyosin using purified enzyme preparations.

\section{Acknowledgements}

The authors are indebted to Professor K. Hashimoto, University of Tokyo, for critical reading of the manuscript. The expenses of the present work were defrayed in part by a Grant-in-Aid for Scientific Research from the Ministry of Education, Science and Culture.

\section{References}

1) H. Arnold and D. Pette: Eur. J. Biochem., 6, 163-171 (1968).

2) H. Arnold and D. Pette: Eur. J. Biochem., 15, 360-366 (1970).

3) H. Arnold, R. Henning, and D. Pette: Eur. J. Biochem., 22, 121-126 (1971).

4) F. M. Clarke and C. J. Masters: Biochim. Biophys. Acta, 381, 37-46 (1975).

5) P. Sigel and D. Pette: J. Histochem. Cytochem., 17, 225-237 (1969).

6) Y.Shimizu, S. Karata, and F. Nishioka: Nippon Suisan Gakkaishi, 42, 1025-1031 (1976).

7) Y. Shimizu and K. Ikeda: Nippon Suisan Gakkaishi, 45, 533-536 (1976).

8) T. Nakagawa and F. Nagayama: Nippon Suisan Gakkaishi, 54, 1971-1974 (1988).

9) F. M. Clarke and C. J. Masters: Biochim. Biophys. Acta, 358, 193-207 (1974).

10) J. A. Spudich and S. Watt: J. Biol. Chem., 264, 4866-4871 (1971).

11) S. Ebashi: J. Biochem., 50, 236-244 (1961).

12) U. K. Laemmli: Nature, 227, 680-685 (1975).

13) T. Nakagawa, S. Watabe, and K. Hashimoto: Nippon Suisan Gakkaishi, 54, 993-998 (1988).

14) M. Okada: Nippon Suisan Gakkaishi, 30, 255- 
261 (1964).

15) F. Clarke, P. Stephan, D. Morton, and J. Weidemann: in "Regulation of Carbohydrate Metabolism" (ed. by R. Beitner), Vol. II, CRC Press, Florida, 1985, pp. 1-31.

16) H. L. A. Tarr and M. Leroux: Can. J. Biochem. Physiol., 40, 571-589 (1962).
17) L. Beis and E. A. Newsholme: Biochem. J., 152, 23-32 (1975).

18) F. Nagayama: Nippon Suisan Gakkaishi, 27, 1014-1017 (1961).

19) W. R. Driedzic and P.W. Hochachka: Amer. J. Physiol., 230, 579-582 (1976). 